\title{
Preventive effects of the novel antimicrobial peptide Nal-P-113 in a rat Periodontitis model by limiting the growth of Porphyromonas gingivalis and modulating IL-1 $\beta$ and TNF- $\alpha$ production
}

\author{
Hong-yan Wang ${ }^{1}$, Li Lin', Wei Fu², Hui-Yuan Yư ${ }^{3}$, Ning Yư ${ }^{4}$, Li-si Tan', Jya-wei Cheng ${ }^{3}$ and Ya-ping Pan ${ }^{1 *}$
}

\begin{abstract}
Background: P-113 (AKRHHGYKRKFH-NH2) is a 12-amino-acid histidine-rich peptide derived from histatin 5 that is highly degradable in high salt concentrations and biological fluids such as serum, plasma and saliva. Nal-P-113, a novel antimicrobial peptide whose histidine residues are replaced by the bulky amino acids $\beta$-naphthylalanine, causes the antimicrobial peptide to retain its bactericidal activity even in physiological environments. This study evaluated the effect of the novel antimicrobial peptide Nal-P-113 in a rat periodontitis model and the mechanisms of action of Nal-P-113 for suppressing periodontitis.

Methods: Periodontitis was induced in mandibular first molars in rats receiving a ligature and infected with Porphyromonas gingivalis. Animals were randomly divided into six groups: $a, P$. gingivalis W83 alone; $b$, P. gingivalis W83 with $6.25 \mu \mathrm{g} / \mathrm{mL}$ of Nal-P-113; C, P. gingivalis W83 with $25 \mu \mathrm{g} / \mathrm{mL}$ of Nal-P-113; $\mathrm{d}$, P. gingivalis W83 with $100 \mu \mathrm{g} / \mathrm{mL}$ of Nal-P-113; e, P. gingivalis W83 with $400 \mu \mathrm{g} / \mathrm{mL}$ of Nal-P-113; and f, control without P. gingivalis W83 or Nal-P-113. Morphometric analysis was used to evaluate alveolar bone loss. Microbiological assessment of the presence of Porphyromonas gingivalis and total bacteria was performed using absolute quantitative real-time PCR and scanning electron microscopy. Gingival tissue was collected for western blot and immunohistochemical assays of IL-1 $\beta$ and TNF-a levels.

Results: Alveolar bone loss was inhibited by $100 \mu \mathrm{g} / \mathrm{mL}$ or $400 \mu \mathrm{g} / \mathrm{mL}$ of Nal-P-113 compared to the control group $(P<0.05)$. Lower amounts of $P$. gingivalis and total bacteria were found in groups $d$ and e compared with group a $(P<0.05)$. A decrease in the levels of IL-1 $\beta$ and TNF-a was detected in group $d$ and group e compared to the control group $(P<0.05)$. The amount of $P$. gingivalis was positively correlated with IL-1 $\beta$ and TNF- $a$ expression in periodontal tissue $(P<0.05)$.

Conclusions: Nal-P-113 exhibited protective effects on Porphyromonas gingivalis-induced periodontitis in rats by limiting the amount of bacteria and modulating IL-1 $\beta$ and TNF-a production. The use of Nal-P-113 in vivo might serve as a beneficial preventive or therapeutic approach for periodontitis.
\end{abstract}

Keywords: Antimicrobial peptide, Animal model, Periodontitis, Alveolar bone loss, Inflammatory response, Porphyromonas gingivalis

\footnotetext{
*Correspondence: yppan_perio@163.com

1 Department of Periodontics and Oral Biology, School of Stomatology, China

Medical University, Shenyang 110002, China

Full list of author information is available at the end of the article
} 


\section{Background}

Chronic periodontitis is the most common oral disease and the leading cause of tooth loss in adults [1]. Furthermore, it is a known risk factor for many systemic diseases [2-4], such as cardiovascular disease, diabetes, and rheumatoid arthritis.

Periodontitis is primarily initiated by exaggerated host immune responses to periodontal pathogens, which lead to the breakdown of periodontal connective tissues and alveolar bone loss [5]. Among numerous periodontal pathogens, the Gram-negative anaerobic bacterium Porphyromonas gingivalis ( $P$. gingivalis) is one of the key pathogens in chronic periodontitis. $P$. gingivalis releases copious amounts of virulence factors, including proteases and lipopolysaccharides, which interact with tolllike receptors or penetrate into periodontal tissues and trigger immune responses, resulting in periodontal tissue destruction. Therefore, eliminating periodontal pathogens, particularly $P$. gingivalis, is essential for blocking the process of periodontitis [5]. Local drug therapy is an effective supplementary means for the treatment of periodontitis, for it can reach areas that curettage instruments can't. Local drug therapies have focused on chlorhexidine and antibiotics such as roxithromycin, spiramycin and metronidazole. Unfortunately, patients have shown poor compliance due to the adverse side effects of these drugs, such as bitter taste, pigmentation, diarrhoea and vomiting. The emergence of drug resistance and dysbacteriosis also limits their clinical application [6, 7]. Therefore, it is urgent to develop novel drugs with few side effects to fight periodontal pathogens. Recently, antimicrobial peptides have become promising antimicrobial agents due to their rapid bactericidal activities and low risk of producing drug-resistant bacterial strains [8]. However, the application of antimicrobial peptides has important drawbacks in vivo due to their high degradation characteristics in the presence of biological fluids [9-12]. Although they demonstrate effective in vitro activities, many antimicrobial peptides have failed in vivo application tests.

P-113 (AKRHHGYKRKFH- $\mathrm{NH}_{2}$ ) is a 12-amino-acid histidine-rich peptide derived from saliva protein histatin 5. Considering its easy degradability, we improved its chemical structure by replacing the histidine residues with bulky amino acid $\beta$-naphthylalanine and synthesized a novel antimicrobial peptide, Nal-P-113. This structural alteration enables Nal-P-113 to be resistant to high salt conditions, including PBS, saliva and bovine calf serum $[13,14]$. The antimicrobial and anti-biofilm effects of the novel antimicrobial peptide Nal-P-113 have been successfully confirmed in our previous in vitro study together with its nontoxic effect on rat gingival tissue. Nevertheless, to date, no study has focused on the impact of Nal-P-113 in inhibiting periodontitis in an animal model. In this study, we explored the effect of locally administered Nal-P-113 in a rat model of periodontitis by measuring alveolar bone loss, microbe colonization and immune-inflammatory modulation. We postulated that Nal-P-113 can prevent periodontal tissue destruction in experimental periodontitis models not only by controlling the amount of pathogens and total bacteria but also by modulating immune-inflammatory factors in gingiva, representing an auxiliary new approach for periodontitis therapy.

\section{Methods}

Synthesis, purification, analysis and dilution of antimicrobial peptide Nal-P-113

Nal-P-113, Ac-AKR-Nal-Nal-GYKRKF-Nal-NH ${ }_{2}$, was synthesized from P-113 (AKRHHGYKRKFH-NH2) by replacing $\mathrm{His} 4,5$ and 12 with $\beta$-naphthylalanines based upon the 9-fluorenylmethoxycarbonyl (Fmoc) solid-phase synthesis protocol $[13,15]$. Electrospray mass spectrometry was used to identify the peptide, and high-performance liquid chromatography (HPLC) was used to assess its purity. The peptide concentration was determined with a UV spectrophotometer at $280 \mathrm{~nm}$. Nal-P-113 was dissolved in sterile deionized water at concentrations of $6.25 \mu \mathrm{g} / \mathrm{mL}$, $25 \mu \mathrm{g} / \mathrm{mL}, 100 \mu \mathrm{g} / \mathrm{mL}$ and $400 \mu \mathrm{g} / \mathrm{mL}$.

\section{Bacteria strains}

The Gram-negative bacterium $P$. gingivalis strain W83 was obtained from the American Type Culture Collection (ATCC) and stored at the Department of Oral Biology, China Medical University. P. gingivalis strain W83 was cultured at $37{ }^{\circ} \mathrm{C}$ for $18 \mathrm{~h}$ in an anaerobic chamber with $85 \% \mathrm{~N}_{2}, 10 \% \mathrm{H}_{2}$, and $5 \% \mathrm{CO}_{2}$ in brain heart infusion broth (Difco, Detroit, MI) supplemented with yeast extract $(5 \mathrm{mg} / \mathrm{mL})$, haemin $(5 \mu \mathrm{g} / \mathrm{mL})$ and vitamin $K_{1}$ $(0.2 \mu \mathrm{g} / \mathrm{mL})$.

\section{Ethical statement}

The use of rats in this study complied with Animal Research Reporting In Vivo Experiments (ARRIVE) guidelines. The experimental protocols were approved by the ethics committee of China Medical University.

\section{Animals}

Five-week-old, healthy, male Sprague Dawley (SD) rats weighing approximately 200-250 g were used. Rats were randomly assigned to one of the following groups (24 rats for each group): a, $P$. gingivalis W83 alone; $P$. gingivalis W83 with b, $6.25 \mu \mathrm{g} / \mathrm{mL}$ of Nal-P-113; c, $25 \mu \mathrm{g} / \mathrm{mL}$ of Nal-P-113; d, $100 \mu \mathrm{g} / \mathrm{mL}$ of Nal-P-113; e, $400 \mu \mathrm{g} / \mathrm{mL}$ of Nal-P-113; and $\mathrm{f}$, control group without $P$. gingivalis W83 or Nal-P-113. 


\section{Induction of rat periodontitis models}

All rats received azithromycin $(10 \mathrm{mg} / 500 \mathrm{~mL})$ for 4 days to reduce the original oral flora before the periodontitis model commenced in a controlled-temperature environment $\left(22 \pm 2{ }^{\circ} \mathrm{C}\right)$. This treatment was followed by a 7 -day antibiotics-free period. At day 0 , rats in all groups (a-f) were anesthetized with $10 \%$ chloral hydrate. A $0.2-\mathrm{mm}$ wire was placed in the dentogingival area of both mandibular first molars. Rats in the experimental groups (a-e) received $1 \times 10^{9} \mathrm{CFU} / \mathrm{mL}(1.5 \mathrm{~mL})$ of $P$. gingivalis W83 in the oral cavity and oesophagus when feeding twice per day (at 8:00 a.m. and 8:00 p.m.). Rats in group f, i.e., the control group, received $1.5 \mathrm{~mL}$ of BHI broth. Two hours later, Nal-P-113 (1 mL) was dripped into the rats' periodontal pockets for $1 \mathrm{~min}$ in groups $b$ to e. Sterile deionized water was dripped into the periodontal pockets in groups a and $\mathrm{f}$. The above procedures continued for four weeks and were accompanied with inhalational anaesthesia with sevoflurane each time (Hengrui Pharmaceutical Co. Ltd., Shanghai, China).

\section{Measurement of alveolar bone loss}

Four weeks later, all rats (144/144) were healthy. After sacrifice by spinal dislocation, the rat mandibles were separated gently from muscle and soft tissue and exposed overnight to $8 \%$ hydrochloric acid. A stereomicroscope (SZX12, Olympus, Japan) equipped with a $12.5 \times$ objective was used for observing the morphology of each rat alveolar bone in every group. YC-2008 $\mu$ micro-measurement software (Aoka, Suzhou, China) was used for measuring the distance between the enamelo-cemental junction and alveolar bone crest along the axis of the teeth. For evaluating the average alveolar bone loss, three points were measured on the buccal and lingual parts along the axis of the teeth. The average bone loss was calculated for each tooth.

\section{Bacterial colonization and distribution}

Unilateral subgingival plaque and bacteria from the buccal and lingual mucosa were collected using sterile toothpicks and stored in $1 \times \mathrm{PBS}$ at $-80{ }^{\circ} \mathrm{C}$. P. gingivalis W83 and total bacteria loads were assessed using absolute quantitative real-time PCR. The primers used were as follows: P. gingivalis W83: F: 5'-CATAGATATCACG AGGAACTCCGATT-3' and R: 5'-AAACTGTTAGCAA CTACCGATGTGG-3'. Universal: F: 5'-AACTGGA GGA AGGTGGGGA-3' and R: $5^{\prime}$-ACGCCAACCTAGTGGAG GA-3'. Each reaction tube contained $20 \mu \mathrm{L}$ of real-time PCR reaction mixture, including $10 \mu \mathrm{L}$ of $2 \times$ SYBR $^{\circ}$ Premix Ex Taq ${ }^{\$}, 0.4 \mu \mathrm{L}$ of $50 \times$ ROX Reference Dye II, $0.8 \mu \mathrm{L}$ of $10 \mu \mathrm{M}$ primers, $0.4 \mu \mathrm{L}$ of template DNA and $6.8 \mu \mathrm{L}$ of $\mathrm{ddH}_{2} \mathrm{O}$. The amplification cycle conditions were $95{ }^{\circ} \mathrm{C}$ for $30 \mathrm{~s}, 40$ cycles of $5 \mathrm{~s}$ each at $95{ }^{\circ} \mathrm{C}$, and $34 \mathrm{~s}$ at $60{ }^{\circ} \mathrm{C}$. The absolute quantities of the target bacteria were determined using standard curves for $P$. gingivalis W83 and total bacteria. Briefly, the DNA concentrations of the target bacterial strains were serially diluted 10 -fold using sterile water to construct standard curves and determine the exact numbers of DNA copies in the samples by calculating ct values. All experiments were performed in triplicate to ensure data accuracy. The data were analysed with ABI 7500 software version 2.0.5 (Applied Biosystems, Foster City, CA, USA) [16].

Contralateral molars were fixed with $2.5 \%$ glutaraldehyde (BioChemika, Fluka), washed with PBS and subsequently dehydrated with ethanol. The processed samples were smeared onto a copper plate followed by gold sputtering, and images of the enamelo-cemental junction of the first molar were acquired by scanning electron microscopy (Inspect F50, FEI Company, USA) at 20,000× magnification. Six views were randomly selected from each animal.

\section{Histopathologic evaluation of periodontal tissue}

All mandibular periodontal tissues and tooth samples were divided in half: the left part was immediately cooled to $-80{ }^{\circ} \mathrm{C}$ for western blotting, and the right part was fixed in $10 \%$ formaldehyde solution at $4{ }^{\circ} \mathrm{C}$ for one week. The samples were washed with distilled water and placed in 10\% EDTA for decalcification for 40 days, rinsed in PBS buffer for $12 \mathrm{~h}$, dehydrated, embedded and cut into 3-4 $\mu \mathrm{m}$ sections for immunohistochemical examination of IL- $1 \beta$ and TNF- $\alpha$ expression in periodontal tissues. Sections were obtained from the tissue that contained tooth, junctional epithelium and gingival tissues. Six views were selected from each sample for mean value calculations. Integrated optical density quantified using a MetaMorph Imaging Microscopic Image Analysis System (UIC, USA) was used to assess the expression of IL- $1 \beta$ and TNF- $\alpha$. The results were recorded as means \pm standard deviations (SD).

\section{Western blot detection of gingival tissue}

Gingival tissue at the buccal root bifurcation was used to examine the levels of IL- $1 \beta$ and TNF- $\alpha$. A total of $20 \mathrm{mg}$ gingival tissue sample was lysed on ice for $30 \mathrm{~min}$ with RIPA lysis buffer containing protease and phosphatase inhibitors (Sigma, St Louis, MO, USA). Supernatant proteins were obtained by centrifugation at $10,000 \times g$ at $4{ }^{\circ} \mathrm{C}$ for $10 \mathrm{~min}$. Total protein was measured with a BCA protein assay kit (Thermo Fisher Scientific, USA). Equal amounts (15 ng) of protein samples were separated by $10 \%$ SDS-polyacrylamide gel electrophoresis (PAGE) at $100 \mathrm{~V}$ for $2 \mathrm{~h}$ and electrotransferred to PVDF membranes (Millipore, Billerica, MA, USA). The membranes were blocked in TBST (20 mM Tris, pH 7.6, $150 \mathrm{mM}$ $\mathrm{NaCl}, 0.1 \%$ Tween 20) containing non-fat dry milk for $2 \mathrm{~h}$ at room temperature and incubated overnight in a 1:800 dilution of anti-IL-1 $\beta$ and anti-TNF- $\alpha$ (Kaiji 
Biological Technology Co. NJ, China) for $2 \mathrm{~h}$. After the membrane was washed three times, it was incubated with a 1:5000 dilution of goat anti-rabbit secondary antibody (Kaiji Biological Technology Co. NJ, China) for $1 \mathrm{~h}$ at room temperature and scanned using a fluorescence system with an anti-GAPDH antibody as an internal reference [17]. A gel imaging analysis system (SYNGENE G: BOX ChemiXR5, USA) and Gel-Pro32 software (Media Cybernetic, Inc., USA) were used for densitometry. Statistical analysis was conducted after calculating integral value/internal reference integral value ratios.

\section{Statistical analysis}

All experiments were performed in triplicate for each condition. An ANOVA was used to compare the significance among groups (SPSS Inc., Chicago, IL, USA). Pearson linear correlation analysis was used to calculate the correlation between $P$. gingivalis, total bacteria DNA replication and the expression of IL- $1 \beta$ and TNF$\alpha$ cytokines. The data are presented as the means \pm standard deviation. A $P$-value $<0.05$ was considered statistically significant.

\section{Results}

\section{Alveolar bone loss}

First, a rat periodontitis model was successfully established by infecting rats with $P$. gingivalis W83 along with placement of a ligature around the first molars of the rats. Alveolar bone loss is a typical characteristic of periodontitis and is usually used as a marker of periodontitis in this model [18]. A stereomicroscope observation showed that rat alveolar bone was severely damaged in groups a, b and c (Fig. 1B-a, b, c). Administration of Nal-P-113 $(100 \mu \mathrm{g} / \mathrm{mL}$ or $400 \mu \mathrm{g} / \mathrm{mL})$ inhibited the destruction of rat alveolar bone in the mandibular first molar during the course of establishing rat periodontitis models, especially at the location of root bifurcation (Fig. 1B-d, e). Based upon YC-2008 software micromeasurement, the results showed severe connective tissue and alveolar bone destruction characterized by an increased distance between the enamelo-cemental junction and alveolar bone crest in the first molars $(1326.40 \pm 186.04 \mu \mathrm{m})$ in group a (Fig. 1A-a). Nal-P$113(100 \mu \mathrm{g} / \mathrm{mL}$ or $400 \mu \mathrm{g} / \mathrm{mL})$ significantly reduced alveolar bone loss in ligated mandibular molars in group $\mathrm{d}$ and e compared to that in group a $(P<0.05)$.
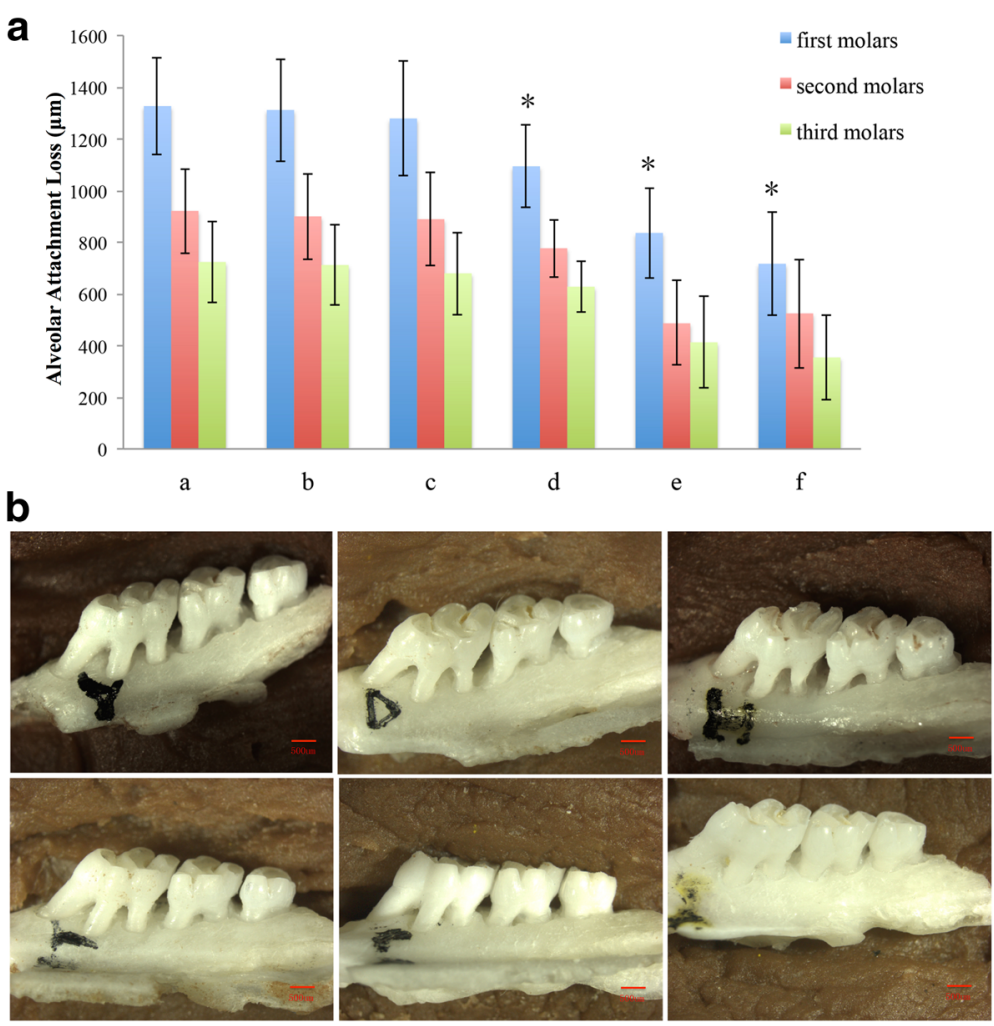

Fig. 1 Detection of rat alveolar bone damage by stereomicroscopy and immunohistochemical staining. (a) and (b) Alveolar bone loss in each group was measured along the long axis of the teeth using a stereomicroscope. a: P. gingivalis W83 alone; b: P. gingivalis W83 plus $6.25 \mu \mathrm{g} / \mathrm{mL}$ of Nal-P-113; c: P. gingivalis W83 plus $25 \mu \mathrm{g} / \mathrm{mL}$ of Nal-P-113; d: P. gingivalis W83 plus $100 \mu \mathrm{g} / \mathrm{mL}$ of Nal-P-113; e: $P$. gingivalis W83 plus $400 \mu \mathrm{gg} / \mathrm{mL}$ of Nal-P-113; f: control group, without P. gingivalis or Nal-P-113. The data are presented as the means of 12 rats in each group (a). The images were selected from each group at random $(\mathbf{b})$ 
The average distance (along the axis of the teeth) between the enamelo-cemental junction and the alveolar bone crest in the first mandibular molars in group $\mathrm{d}$ and group e was $1094.40 \pm 159.04 \mu \mathrm{m}$ and $836.20 \pm 175.03 \mu \mathrm{m}$, respectively $(P<0.05$, Fig. 1A-d and Fig. 1A-e).

\section{P. gingivalis W83 and total bacteria loads}

A large amount of bacteria (mainly Coccus) present as a biofilm on the surface of teeth could be observed in group $\mathrm{f}$ (Fig. 2A-f), which confirmed that the resident flora in the rats' oral cavity was Coccus. Three-dimensional biofilms composed of Coccus and Bacillus brevis aggregated on the surface of teeth after feeding $P$. gingivalis W83. Administration of Nal-P-113 $(100 \mu \mathrm{g} / \mathrm{mL}$ or $400 \mu \mathrm{g} / \mathrm{mL})$ inhibited dental plaque biofilms in the rat oral cavity, resulting in only few Coccus or Bacillus brevis colonies scattered on the surface of teeth (Fig. 2A-d and Fig. 2A-e). To further quantify the amounts of bacteria colonizing the rat oral cavity, absolute quantitative real-time PCR was performed to detect $P$. gingivalis W83 and total bacteria. The results illustrated that Nal-P-113 at high concentrations $(100 \mu \mathrm{g} / \mathrm{mL}$ or $400 \mu \mathrm{g} / \mathrm{mL})$ significantly reduced $P$. gingivalis W83 and total bacteria loads $(P<0.05$, Table 1$)$.

\section{Expression of IL-1 $\beta$ and TNF- $\alpha$}

Immunohistochemical staining was performed, and the percentage of inflammatory cells, including neutrophils, lymphocytes and monocytes, was counted in 6 randomly selected views at $400 \times$ magnification. The results showed that in groups a and $b$, the percentage of inflammatory cells was $>75 \%$, accompanied by epithelial spike thickening, periodontal ligament fibre degeneration and alveolar bone damage (Fig. 3A,B-a and Fig. 3A,B-b). In group a, large amounts of IL- $1 \beta$ and TNF- $\alpha$ were found in the periodontal tissue, specifically, the integrated optical density of IL- $1 \beta$ and TNF- $\alpha$ in periodontal tissue was $54.26 \pm 2.94$ and $27.11 \pm 1.60$, respectively. Compared to group a, rats in group $\mathrm{b}$ and group $\mathrm{c}$ demonstrated a slight reduction of IL- $1 \beta$ and TNF- $\alpha$ levels in periodontal tissue (Fig. 3A,B-b and Fig. 3A,B-c), but the differences were not statistically significant $(P>0.05$, Table 2$)$. With increasing concentrations of Nal-P-113, IL- $1 \beta$ and TNF- $\alpha$ levels in periodontal tissue declined dramatically in group $\mathrm{d}$ and group $\mathrm{e}$ $(P<0.05$, Table 2$)$. Additionally, fewer inflammatory cells $(<50 \%)$ could be found around the alveolar bone, and the gingival epithelium attached itself closely to the alveolar bone with little periodontal ligament fibre breakage (Fig. 3A,B-d and Fig. 3A,B-e).

Western blot data were consistent with the finding that Nal-P-113 reduced IL-1 $\beta$ and TNF- $\alpha$ expression in gingival tissue in a concentration-dependent manner. In group a, the adjusted values for IL-1 $\beta / G A P D H$ and TNF- $\alpha$ /GAPDH were 0.71 and 0.75 , respectively. Four doses of Nal-P-113 all reduced IL-1 $\beta$ and TNF- $\alpha$ levels in gingival tissue compared to those in group a, even though the expression of TNF- $\alpha$ was slightly increased in group c compared with group b (Fig. 3C).

\section{Correlation between $P$. gingivalis DNA replication and cytokine expression}

A Pearson linear correlation analysis was used to evaluate the correlation between bacterial DNA ( $P$. gingivalis and total bacteria) and the expression of IL-1 $\beta$ and TNF- $\alpha$ cytokines. The results showed that both IL-1 $\beta$ and TNF- $\alpha$ expression in periodontal tissue were positively correlated with the copies of $P$. gingivalis DNA (Fig. 4A. IL-1 $\beta: R=0.947, P=0.004$; TNF- $\alpha: R=0.960$,
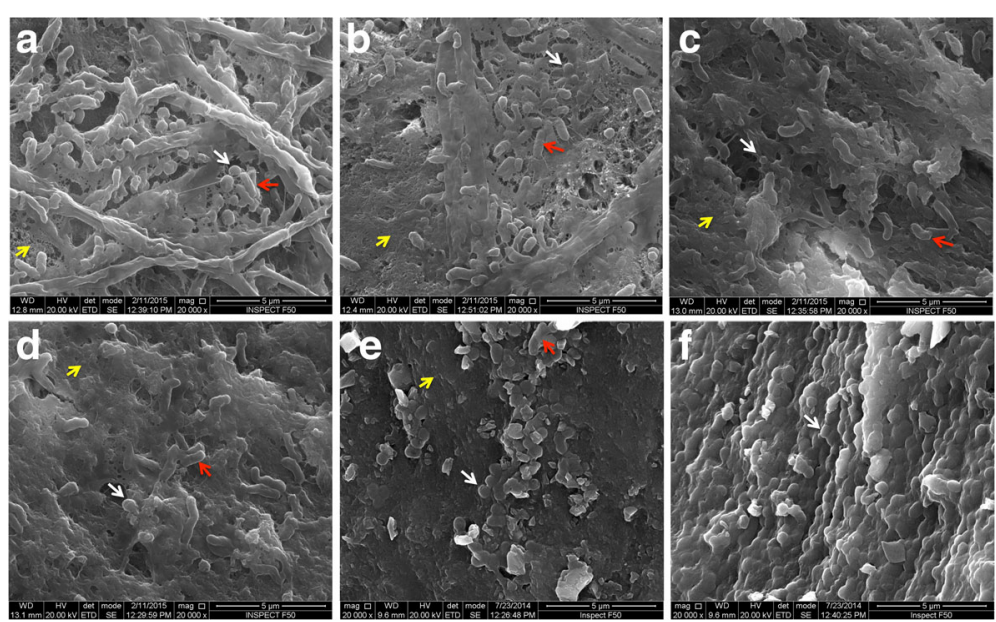

Fig. 2 Bacteria on enamelo-cemental junction of rats' teeth detected by scanning electron microscopy. a: P. gingivalis W83 alone; b: P. gingivalis W83 plus $6.25 \mu \mathrm{g} / \mathrm{mL}$ of Nal-P-113; c: P. gingivalis W83 plus $25 \mu \mathrm{g} / \mathrm{mL}$ of Nal-P-113; d: P. gingivalis W83 plus $100 \mu \mathrm{g} / \mathrm{mL}$ of Nal-P-113; e: P. gingivalis W83 plus $400 \mu \mathrm{g} / \mathrm{mL}$ of Nal-P-113; f: control group, without P. gingivalis W83 or Nal-P-113. SEM magnification, 20,000x. Red arrows indicate $P$. gingivalis W83; white arrows indicate Coccus, a genus of resident bacteria in the rat oral cavity; yellow arrows indicate the rat tooth surface 
Table 1 DNA copy numbers of $P$. gingivalis W83 and total bacteria loads

\begin{tabular}{lllllll}
\hline & group a & group b & group $c$ & group d & group e & group $f$ \\
\hline P. gingivalis W83 & $(1.74 \pm 0.12) \mathrm{E}+17$ & $(1.71 \pm 0.10) \mathrm{E}+17$ & $(1.69 \pm 0.11) \mathrm{E}+17$ & $(1.06 \pm 0.034) \mathrm{E}+17^{\mathrm{a}}$ & $(6.21 \pm 0.24) \mathrm{E}+16^{\mathrm{a}}$ & - \\
Total bacteria & $(2.19 \pm 0.29) \mathrm{E}+20$ & $(2.03 \pm 0.10) \mathrm{E}+20$ & $(1.98 \pm 0.05) \mathrm{E}+20$ & $(1.01 \pm 0.051) \mathrm{E}+20^{\mathrm{a}}$ & $(6.97 \pm 0.61) \mathrm{E}+19^{\mathrm{a}}$ & $(1.89 \pm 0.071) \mathrm{E}+20$
\end{tabular}

${ }^{\mathrm{a}} P<0.05$, compared with group a

$P=0.002)$. Nevertheless, the total bacterial DNA did not correlate with IL-1 $\beta$ or TNF- $\alpha$ expression (Fig. 4B. IL-1 $\beta$ : $R=0.622, P=0.187$; TNF- $\alpha: R=0.573, P=0.235$ ).

\section{Discussions}

Periodontitis is a complex disorder dependent on many factors, but inflammatory cell accumulation induced by microorganisms in periodontal tissues is considered the primary causative factor. $P$. gingivalis, a member of the red complex, is considered one of the most important pathogenic factors of periodontitis, which produces several virulence factors, including lipopolysaccharide, capsules, fimbriae and a group of proteolytic enzymes that damage periodontal tissue [19-21]. In addition, $P$. gingivalis can trigger changes to the amount and composition of the oral commensal microbiota, leading to inflammatory periodontal bone loss [22]. In this condition, the removal of periodontal pathogens, such as $P$. gingivalis, is

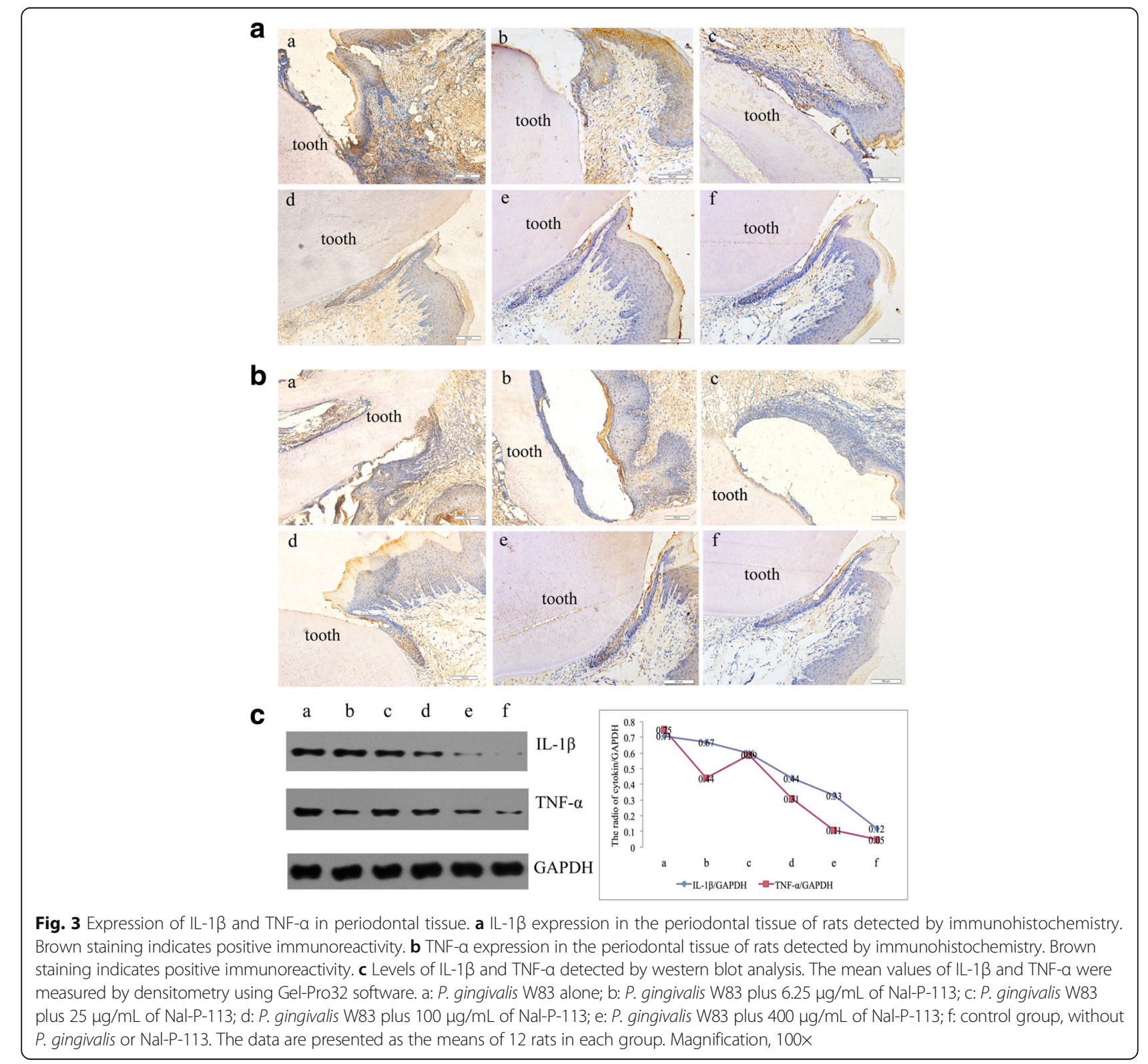


Table 2 Integrated optical densities of the immunohistochemical staining for IL-1 $\beta$ and TNF- $\alpha$

\begin{tabular}{lllllll}
\hline & Controls & $P$ gingivalis & Nal-P-113 $(n=12)$ & & & \\
\cline { 5 - 7 } & $(n=12)$ & $(n=12)$ & $6.25 \mu \mathrm{g} / \mathrm{mL}$ & $25 \mu \mathrm{g} / \mathrm{mL}$ & $100 \mu \mathrm{g} / \mathrm{mL}$ & $400 \mu \mathrm{g} / \mathrm{mL}$ \\
\hline IL-1 $\beta$ & $5.32 \pm 0.93$ & $54.26 \pm 2.94$ & $49.32 \pm 9.81$ & $40.50 \pm 5.61$ & $19.78 \pm 3.40^{\text {a }}$ & $12.40 \pm 2.51^{\mathrm{a}}$ \\
TNF- $a$ & $4.63 \pm 0.57$ & $27.11 \pm 1.60$ & $24.63 \pm 5.17$ & $20.94 \pm 3.77$ & $12.62 \pm 2.67^{\mathrm{a}}$ & $9.09 \pm 2.07^{\mathrm{a}}$ \\
\hline
\end{tabular}

${ }^{\mathrm{a}} P<0.05$, compared with the $P$. gingivalis group

an effective method to block chronic periodontitis. Although periodontal pathogens are required for disease initiation, the extent and severity of periodontal damage depend on the nature of the host response to bacterial challenge. The development of a novel therapeutic strategy combining both the antibacterial activity and the host-modulatory effect of a new drug could increase the likelihood of successfully managing periodontitis [23]. Some studies have shown that antimicrobial peptides, in addition to exhibiting a direct antimicrobial activity, possess a wide range of immunomodulatory properties [24]. In animal models, researchers have verified that antimicrobial peptides are effective in oral Candidiasis infection, lung infection and sinusitis [25-27], but few studies have focused on periodontitis therapy in vivo. The present study evaluated, for the first time, the anti-inflammatory and antimicrobial impact of a novel antimicrobial peptide Nal-P-113 in preventing the progression of periodontitis in a concentration-dependent manner.

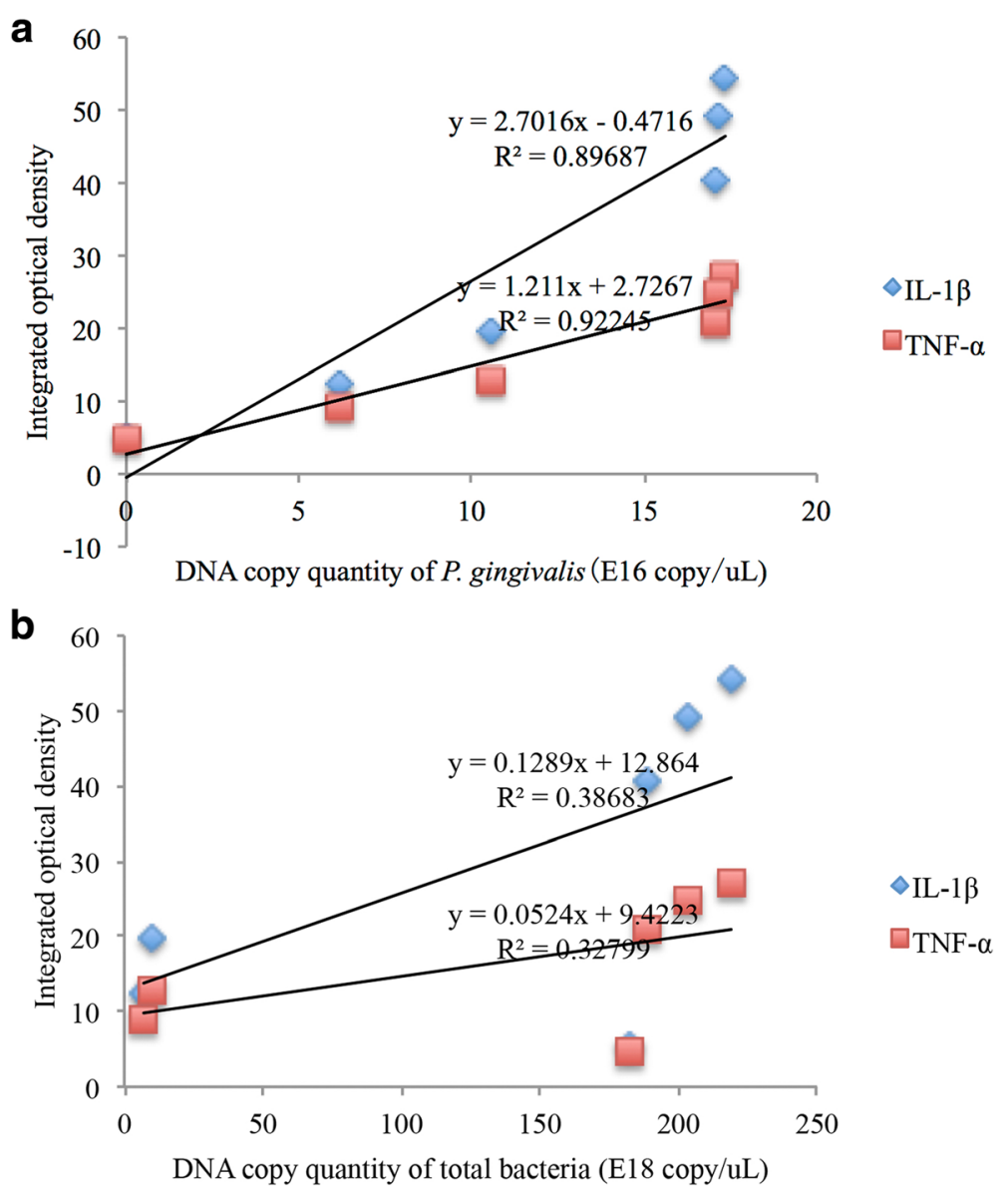

Fig. 4 a Linear correlation curve of the P. gingivalis' DNA copy number and cytokines in periodontal tissue (IL-1 $\beta$ and TNF-a). The integrated optical densities of IL-1 $\beta$ and TNF-a were calculated on the basis of immunohistochemical staining. The levels of IL-1 $\beta$ and TNF-a in rat periodontal tissue showed a significant positive linear correlation with DNA copy number of $P$. gingivalis $(P<0.05)$. $\mathbf{b}$ Linear correlation curve of the total bacteria DNA copy number and cytokines in periodontal tissue (IL-1 $\beta$ and TNF- $a$ ). The integrated optical densities of IL-1 $\beta$ and TNF-a were calculated on the basis of immunohistochemical staining. There was not a significant positive linear correlation between IL-1 $\beta$ or TNF-a expression levels in rat periodontal tissue and DNA copy number of total bacteria $(P>0.05)$ 
In the current investigation, morphometric analysis demonstrated that therapy with Nal-P-113 promoted a significant decrease in bone loss compared to high periodontal breakdown in the non-treated group. The enamelo-cemental junction area served as an observation locus to explore the bacterial distribution on the rat tooth surface. Scanning electron microscopy showed that bacteria adhering to the surfaces of teeth in a scattered distribution were impacted by high concentrations of Nal-P-113. Consistent with the morphological images, quantitative real-time PCR confirmed the results that treatment with $100 \mu \mathrm{g} / \mathrm{mL}$ or $400 \mu \mathrm{g} / \mathrm{mL}$ of Nal-P-113 reduced the amount of $P$. gingivalis and total bacteria loads compared with those in the control group $(P<0.05)$. A previous study showed that Nal-P-113 inhibited bacterial growth even caused bacterial death by permeabilizing and/or forming pores within cytoplasmic membranes in a concentration-dependent manner in vitro [14]. The present study demonstrated the ability of the novel antimicrobial peptide Nal-P-113 to inhibit biofilm formation, local inflammatory response and alveolar bone loss in an experimental rat periodontitis model.

Bacteria are essential for the development of periodontitis but not sufficient to cause disease alone. For periodontitis to develop, a susceptible host is required [28, 29]. Page et al. in 1999 reported that periodontal disease was characterized by high concentrations of matrix metalloproteinases (MMPs), cytokines, and prostaglandins in the periodontal tissue.23 Certain cytokines, including IL-1 $\beta$ and TNF- $\alpha$, play a critical role in the pathogenesis of periodontitis. IL- $1 \beta$ and TNF- $\alpha$ are both pro-inflammatory cytokines involved in the induction of several other inflammatory mediators in periodontal inflammation, such as IL-6, chemokines, MMPs and prostaglandin $E_{2}$ [30]. Furthermore, IL-1 $\beta$ and TNF- $\alpha$ can induce secondary mediators, resulting in inflammatory response expansion, connective tissue destruction and osteoclastic bone resorption [31]. To explore the host involvement in the disease process, immunohistochemical techniques and western blotting were used to detect IL-1 $\beta$ and TNF- $\alpha$ expression in the periodontal tissue of rats. The results showed that Nal-P-113 reduced IL-1 $\beta$ and TNF- $\alpha$ levels in periodontal tissue in a concentration-dependent manner. Many scholars have also confirmed that other antimicrobial peptides were capable of modulating innate immunity [32-34]. For example, Pingel et al. reported that human beta-defensin (hBD)-3 significantly decreased the secretion of IL-6, IL-10, GM-CSF and TNF- $\alpha$ by human myeloid dendritic cells stimulated with recombinant Porphyromonas gingivalis hemagglutinin B [34]. LL-37 induced production of pro-inflammatory cytokines IL-4, IL-5 and IL-1 $\beta$ from human mast cell [35] or by activation of P2X7 receptor from monocytes [36]. Some immune cells, such as macrophages or mast cells, can express G protein-coupled receptors and have a role in both innate immune responses and antimicrobial activation [24]. But in our study, we didn't find Nal-P-113 alone change IL-1 $\beta$ or TNF- $\alpha$ levels in macrophages (Additional file 1: Figure S1). Other immune cells, such as mast cells, monocytes and neutrophils interact with Nal-P-113 should be investigated in the future studies.

It is worth noting that the TNF- $\alpha$ level detected by western blotting was slightly increased when $25 \mu \mathrm{g} / \mathrm{mL}$ of antimicrobial peptide Nal-P-113 was used. One potential explanation might be that antimicrobial peptides themselves can induce a slight up-regulation of TNF- $\alpha$ expression [37]. Our results showed that $25 \mu \mathrm{g} / \mathrm{mL}$ or $400 \mu \mathrm{g} / \mathrm{mL}$ Nal-P-113 increased TNF- $\alpha$ expression levels in human periodontal ligament stem cells, but not in immortalized human gingival epithelial cells or macrophages (Additional file 1: Figure S1). The specific mechanism is not clear, maybe it decreased the MyD88 and AKT levels to affect the NF- $\mathrm{KB}$ signaling pathway and modulated TNF- $\alpha$ response [38]. To some extent, the host-defence mechanisms are sustained by an large network of anti- and pro-inflammatory mediators that may exert antagonistic and/or synergistic biological activities, further studies are required to better understand the role of Nal-P-113 in the modulation of immune-inflammatory responses.

Based on the correlation analysis, IL- $1 \beta$ and TNF- $\alpha$ levels in gingival tissue were positively correlated with $P$. gingivalis but not with the total amount of bacteria. Therefore, in the process of host-microbial interactions, $P$. gingivalis played a more important role in promoting IL- $1 \beta$ and TNF- $\alpha$ expression than other oral bacteria. We surmise that the antimicrobial peptide Nal-P-113 might interrupt pre-inflammatory cytokine expression by reducing $P$. gingivalis loads in the rat oral cavity.

\section{Conclusions}

Overall, the present investigation demonstrates that a novel antimicrobial peptide, Nal-P-113, not only overcomes the degradation susceptibility of antimicrobial peptides in vivo but also exerts potent preventive effects on rat periodontitis. This peptide inhibits $P$. gingivalis-induced local inflammatory response and alveolar bone loss by reducing the amount of bacteria directly and down-regulating pro-inflammatory molecules such as IL- $1 \beta$ and TNF- $\alpha$. Though further studies are needed to determine the exact mechanism of hostmicrobial interactions in periodontitis treated with antimicrobial peptides, these agents have the potential to be used as a new preventive or therapeutic strategy for chronic periodontitis in the clinic. 


\section{Additional file}

Additional file 1: Figure S1. (A) IL-1 $\beta$ levels of immortalized human gingival epithelial cells, human periodontal ligament stem cells and macrophages after co-cultured with Nal-P-113 for 2 h. Nal-P-113 $(25 \mu \mathrm{g} / \mathrm{mL}$ or $400 \mu \mathrm{g} / \mathrm{mL}$ ) did not change the levels of IL-1 $\beta$ expression in immortalized human gingival epithelial cells, human periodontal ligament stem cells or macrophages detected by enzyme-linked immunosorbent assay $(P>0.05)$. (B) TNF-a levels of immortalized human gingival epithelial cells, human periodontal ligament stem cells and macrophages after co-cultured with Nal-P-113 for 2 h. Nal-P-113 (25 $\mathrm{gg} / \mathrm{mL}$ or $400 \mu \mathrm{g} / \mathrm{mL})$ increased TNF-a levels in periodontal ligament cells $(P<0.05)$, but not in gingival epithelial cells or macrophages $(P>0.05)$. (JPEG $453 \mathrm{~kb})$

\section{Abbreviations}

CFU: Colony forming units; HPLC: High-performance liquid chromatography; IL-1 $\beta$ : interleukin-1 beta; MMPs: Matrix metalloproteinases; qPCR: Quantitative PCR; SD rats: Sprague Dawley rats; SEM: Scanning electron microscopy; TNFa: tumour necrosis factor-alpha.

\section{Acknowledgements}

None.

\section{Funding}

This work is supported by grants from the Natural Science Foundation of China (no. 81470745 to YPP); the Minister of Science and Technology, Taiwan (MOST103-2113-M-007-009-MY2 to JWC); and the Natural Science Foundation of Liaoning Province (no. 2014021067 to LL and 2015020754 to HYW).

\section{Availability of data and materials}

All data and analyses in the current study are available from the corresponding author upon reasonable request.

\section{Authors' contributions}

HYW established the animal model, analysed and interpreted the data, and drafted the manuscript. LL maintained the $P$. gingivalis W83 culture and performed real-time PCR testing. WF participated in writing the paper and data analysis. HYY performed the immunohistochemical analysis. NY was responsible for western blotting. LST performed the alveolar bone loss analysis. JWC and YPP designed the study and drafted the manuscript. All authors read and approved the final manuscript.

\section{Ethics approval and consent to participate}

The use of rats in this study complied with Animal Research Reporting In Vivo Experiments (ARRIVE) guidelines. The experimental protocols were approved by the Ethics Committee of China Medical University.

\section{Consent for publication}

Not applicable.

\section{Competing interests}

The authors declare that they have no competing interests.

\section{Publisher's Note}

Springer Nature remains neutral with regard to jurisdictional claims in published maps and institutional affiliations.

\section{Author details}

'Department of Periodontics and Oral Biology, School of Stomatology, China Medical University, Shenyang 110002, China. '2Department of Pharmacy, Tongji Hospital Affiliated with Tongji Medical College, Huazhong University of Science and Technology, Wuhan 430030, China. ${ }^{3}$ Institute of Biotechnology and Department of Medical Science, National Tsing Hua University, Hsinchu 300, Taiwan. ${ }^{4}$ Department of Periodontics and Oral Medicine, University of Michigan, School of Dentistry, Ann Arbor, MI, USA.
Received: 13 December 2016 Accepted: 17 August 2017

Published online: 29 August 2017

\section{References}

1. Pihlstrom BL, Michalowicz BS, Johnson NW. Periodontal diseases. Lancet. 2005;366(9499):1809-20.

2. Shrihari TG. Potential correlation between periodontitis and coronary heart disease-an overview. Gen Dent. 2012;60(1):20-4

3. Carallo C, De Franceschi MS, Tripolino C, Figliuzzi M, Irace C, Fortunato L, Gnasso A. Common carotid and brachial artery hemodynamic alterations in periodontal disease. J Clin Periodontol. 2013:40(5):431-6.

4. Kebschull M, Haupt M, Jepsen S, Deschner J, Nickenig G, Werner N. Mobilization of endothelial progenitors by recurrent bacteremias with a periodontal pathogen. PLoS One. 2013;8(1):e54860.

5. Baker PJ, Dixon M, Evans RT, Dufour L, Johnson E, Roopenian DC. CD4(+) T cells and the proinflammatory cytokines gamma interferon and interleukin6 contribute to alveolar bone loss in mice. Infect Immun. 1999:67(6):2804-9.

6. Wilson BT, Strong A, O'Kelly S, Munkley J, Stark Z. Metronidazole toxicity in Cockayne syndrome: a case series. Pediatrics. 2015;136(3):e706-8.

7. Terlemez S, Eryilmaz U, Tokgoz Y, Uysal P, Cosan A, Bulut Y. Kounis syndrome caused by metronidazole-a case of 14 year-old boy. Int J Cardiol. 2015;179:222-4.

8. Hancock RE, Lehrer R. Cationic peptides: a new source of antibiotics. Trends Biotechnol. 1998;16(2):82-8.

9. Koshlukova SE, Lloyd TL, Araujo MW, Edgerton M. Salivary histatin 5 induces non-lytic release of ATP from Candida Albicans leading to cell death. J Biol Chem. 1999;274(27):18872-9.

10. Murakami Y, Xu T, Helmerhorst EJ, Ori G, Troxler RF, Lally ET, Oppenheim FG. Inhibitory effect of synthetic histatin 5 on leukotoxin from Actinobacillus actinomycetemcomitans. Oral Microbiol Immunol. 2002;17(3):143-9.

11. Baranska-Rybak W, Sonesson A, Nowicki R, Schmidtchen A. Glycosaminoglycans inhibit the antibacterial activity of LL-37 in biological fluids. J Antimicrob Chemother. 2006;57(2):260-5.

12. Jang WS, Li XS, Sun JN, Edgerton M. The P-113 fragment of histatin 5 requires a specific peptide sequence for intracellular translocation in Candida Albicans, which is independent of cell wall binding. Antimicrob Agents Chemother. 2008:52(2):497-504.

13. Yu HY, Tu CH, Yip BS, Chen HL, Cheng HT, Huang KC, Lo HJ, Cheng JW. Easy strategy to increase salt resistance of antimicrobial peptides. Antimicrob Agents Chemother. 2011;55(10):4918-21.

14. Wang HY, Cheng JW, Yu HY, Lin L, Chih YH, Pan YP. Efficacy of a novel antimicrobial peptide against periodontal pathogens in both planktonic and polymicrobial biofilm states. Acta Biomater. 2015:25:150-61.

15. Lin IJ, Lou YC, Pai MT, Wu HN, Cheng JW. Solution structure and RNAbinding activity of the $\mathrm{N}$-terminal leucine-repeat region of hepatitis delta antigen. Proteins. 1999;37(1):121-9.

16. Yang $X, L i C$, Pan $Y$. The influences of periodontal status and periodontal pathogen quantity on salivary 8-Hydroxydeoxyguanosine and interleukin-17 levels. J Periodontol. 2016;87(5):591-600.

17. Pan $C, X u X$, Tan $L$, Lin $L$, Pan $Y$. The effects of Porphyromonas gingivalis on the cell cycle progression of human gingival epithelial cells. Oral Dis. 2014; 20(1):100-8

18. Zhou T, Chen D, Li Q, Sun X, Song Y, Wang C. Curcumin inhibits inflammatory response and bone loss during experimental periodontitis in rats. Acta Odontol Scand. 2013;71(2):349-56.

19. Sheets SM, Robles-Price AG, McKenzie RM, Casiano CA, Fletcher HM. Gingipain-dependent interactions with the host are important for survival of Porphyromonas gingivalis. Front Biosci J Virtual Libr. 2008;13:3215-38.

20. Irshad M, van der Reijden WA, Crielaard W, Laine ML. In vitro invasion and survival of Porphyromonas gingivalis in gingival fibroblasts; role of the capsule. Arch Immunol Ther Exp. 2012:60(6):469-76.

21. Kristoffersen AK, Solli SJ, Nguyen TD, Enersen M. Association of the rgpB gingipain genotype to the major fimbriae (fimA) genotype in clinical isolates of the periodontal pathogen Porphyromonas gingivalis. J Oral Microbiol. 2015:7:29124.

22. Hajishengallis G, Liang S, Payne MA, Hashim A, Jotwani R, Eskan MA, McIntosh ML, Alsam A, Kirkwood KL, Lambris JD, et al. Low-abundance biofilm species orchestrates inflammatory periodontal disease through the commensal microbiota and complement. Cell Host Microbe 2011; 10(5):497-506. 
23. Pimentel SP, Barrella GE, Casarin RC, Cirano FR, Casati MZ, Foglio MA, Figueira GM, Ribeiro FV. Protective effect of topical Cordia Verbenacea in a rat periodontitis model: immune-inflammatory, antibacterial and morphometric assays. BMC Complement Altern Med. 2012;12:224

24. Pundir P, Kulka M. The role of $G$ protein-coupled receptors in mast cell activation by antimicrobial peptides: is there a connection? Immunol Cell Biol. 2010;88(6):632-40.

25. Song Z, Wu H, Mygind P, Raventos D, Sonksen C, Kristensen HH, Hoiby N. Effects of intratracheal administration of novispirin G10 on a rat model of mucoid Pseudomonas Aeruginosa lung infection. Antimicrob Agents Chemother. 2005;49(9):3868-74.

26. Chennupati SK, Chiu AG, Tamashiro E, Banks CA, Cohen MB, Bleier BS, Kofonow JM, Tam E, Cohen NA. Effects of an LL-37-derived antimicrobial peptide in an animal model of biofilm pseudomonas sinusitis. Am J Rhinol Allergy. 2009;23(1):46-51

27. Ryan LK, Freeman KB, Masso-Silva JA, Falkovsky K, Aloyouny A, Markowitz K, Hise AG, Fatahzadeh M, Scott RW, Diamond G. Activity of potent and selective host defense peptide mimetics in mouse models of oral candidiasis. Antimicrob Agents Chemother. 2014;58(7):3820-7.

28. Page RC. Milestones in periodontal research and the remaining critical issues. J Periodontal Res. 1999;34(7):331-9.

29. Elavarasu S, Sekar S, Murugan T. Host modulation by therapeutic agents. J Pharm Bioallied Sci. 2012;4(Suppl 2):S256-9.

30. Souza PP, Lerner UH. The role of cytokines in inflammatory bone loss, Immunol Investig. 2013;42(7):555-622.

31. Beklen A, Ainola M, Hukkanen M, Gurgan C, Sorsa T, Konttinen YT. MMPs, II-1, and TNF are regulated by IL-17 in periodontitis. J Dent Res. 2007;86(4):347-51.

32. Silva ON, de la Fuente-Nunez C, Haney EF, Fensterseifer IC, Ribeiro SM, Porto WF, Brown P, Faria-Junior C, Rezende TM, Moreno SE, et al. An anti-infective synthetic peptide with dual antimicrobial and immunomodulatory activities. Sci Rep. 2016;6:35465.

33. Diamond G, Beckloff N, Weinberg A, Kisich KO. The roles of antimicrobial peptides in innate host defense. Curr Pharm Des. 2009;15(21):2377-92.

34. Pingel LC, Kohlgraf KG, Hansen CJ, Eastman CG, Dietrich DE, Burnell KK, Srikantha RN, Xiao X, Belanger M, Progulske-Fox A, et al. Human betadefensin 3 binds to hemagglutinin B (rHagB), a non-fimbrial adhesin from Porphyromonas gingivalis, and attenuates a pro-inflammatory cytokine response. Immunol Cell Biol. 2008;86(8):643-9.

35. Yoshioka M, Fukuishi N, Kubo Y, Yamanobe H, Ohsaki K, Kawasoe Y, Murata M, Ishizumi A, Nishii Y, Matsui N, et al. Human cathelicidin CAP18/LL-37 changes mast cell function toward innate immunity. Biol Pharm Bull. 2008; 31(2):212-6.

36. Elssner A, Duncan M, Gavrilin M, Wewers MD. A novel P2X7 receptor activator, the human cathelicidin-derived peptide LL37, induces IL-1 beta processing and release. J Immunol (Baltimore, Md : 1950). 2004;172(8):4987-94.

37. Hwang $S A$, Kruzel ML, Actor JK. Immunomodulatory effects of recombinant lactoferrin during MRSA infection. Int Immunopharmacol. 2014;20(1):157-63.

38. Zong X, Hu W, Song D, Li Z, Du H, Lu Z, Wang Y. Porcine lactoferrin-derived peptide LFP-20 protects intestinal barrier by maintaining tight junction complex and modulating inflammatory response. Biochem Pharmacol. 2016; 104:74-82.

\section{Submit your next manuscript to BioMed Central and we will help you at every step:}

- We accept pre-submission inquiries

- Our selector tool helps you to find the most relevant journal

- We provide round the clock customer support

- Convenient online submission

- Thorough peer review

- Inclusion in PubMed and all major indexing services

- Maximum visibility for your research

Submit your manuscript at www.biomedcentral.com/submit

Biomed Central 